\title{
MAJOR DISEASES OF NILE CROCODILE (Crocodylus niloticus) WITH FOCUS ON CURRENT STATUS IN ARBA MINCH CROCODILE RANCH, ETHIOPIA
}

\author{
Kasahun DELENE ${ }^{1}$, Alemayehu LEMMA ${ }^{1}$ and Haben FESSEHA ${ }^{2} \bowtie$ \\ ${ }^{1}$ College of Veterinary Medicine, Addis Ababa University, P.O Box 34, Addis Ababa, Ethiopia. \\ 2School of Veterinary Medicine, Wolaita Sodo University, P.O Box 138, Wolaita Sodo, Ethiopia. \\ Email: tseyon.h@mail.com; (D) ORCiD: 0000-0001-6516-3036 \\ supporting Information
}

\begin{abstract}
Crocodylus niloticus is found in 26 African countries including Ethiopia, the largest recorded specimen measuring 17.0 feet Nile crocodile from the Gambela Upeno River in 1969. Its presence and absence also depend on the climatic conditions and the environment (i.e. the landscape for basking and feeding). In Ethiopia, Nile crocodiles have a mating period during September to October, Nesting occurs in the dry season December to January, and hatchling takes place at the onset of the rainy season, i.e. March/April months. Over the period of 2007-2016 an average of 201,000 Crocodylus niloticus skins were exported globally per year, with an increasing trend over the period 2009-2016. Besides the management problems, at Arba Minch Crocodile Ranch, Nile crocodiles are suffering from nutritional abnormalities and health problems. The diseases of the Nile crocodile are classified as infectious (transmissible) and non-infectious (non-transmissible). A transmissible crocodile disease includes bacterial, viral, fungal, protozoan, and parasitic diseases; non-transmissible crocodile diseases are nutritional, toxic poisonings and metabolic disorders; other diseases like nutritional bone diseases and skin lesions are the major health problems at Arba Minch Crocodile Ranch. The main aim of this review is to highlight the major diseases and management status of Crocodylus niloticus in Arba Minch ranches, Ethiopia. In conclusion, the Arba Minch Crocodile Ranch (AMCR) should exercise care and caution when introducing hatchlings from the wild into the Ranch and enhance its husbandry methods to reduce the occurrence of infection and disease. It must also work with professionals and research groups.
\end{abstract}

Keywords: Arba-Minch, Crocodylus niloticus, Diseases, Nile crocodile.

\section{INTRODUCTION}

Reptiles are considered ectothermic (Seebacher, 1999, Modesto and Anderson, 2004) and due to their environmental thermal limit, most reptile species distribution tends to be near the tropics (Summers, 2015). Crocodiles are classified as the largest reptiles grouped under family Crocodylidae (Huchzermeyer, 2003). They belong to the great group called archosaurs (ruling reptiles), which also included extinct thecodonts. Crocodilians of today are the most social reptiles (Shine, 1988) all belong to the clade Eusuchia (Summers 2015); For the last few decades, and until quite recently, 23 species of modern crocodilians in eight genera were recognized currently there are 27 species in nine genera (Grigg, 2015). Which comprises of 27 species and sub-species, all belonging to a single-family called the Crocodylidae (Summers 2015). When the taxonomy is resolved, there are likely to be $\sim 30$ species recognized (Grigg, 2015).

Crocodiles are widespread throughout sub-Saharan Africa (Leslie and Spotila, 2001). There are five species of crocodiles in Africa, the African dwarf crocodile (Osteolaemus tetraspis), the Central African slender-snouted crocodile (Mecistops leptorhynchus), the West African slender-snouted crocodile (Mecistops cataphractus), the West African crocodile (Crocodylus suchus) and the Nile crocodile (Crocodylus niloticus) (Shirley et al., 2018). The Nile crocodile is among the largest and best known biologically of all the crocodilians. Nile crocodiles are widely distributed throughout sub-Saharan Africa, and historical records indicate its range formerly extended into southern Israel and Jordan. The species was also established on the Comoros Islands and still exists in Madagascar (Ross, 1998).

The Nile crocodile was once abundant in Ethiopia's rivers and lakes. By 1971, the head of the Wildlife Conservation Department had already considered the Nile crocodile to be seriously depleted but they were protected only in reserves like Omo Game (Nechsar National) Park. Subsequently, in 1972 commercial hunting of crocodiles was prohibited in Ethiopia and the Nile crocodile was listed as a game animal that could be hunted under permit only. Ethiopia ratified the Convention on International Trade in Endangered Species of Wild Fauna and Flora (CITES), in 1989. The Nile crocodile was transferred from Appendix I, the highest order of protection, under the convention, to Appendix II to allow an export quota 
for ranched skins (referring to crocodiles raised from wild-collected eggs and/or hatchlings). The initial export quotas approved by CITES were 9370 for 1990 and 8870 for 1991-92 (Whitaker, 2007), but this has reduced to 3000 for ranched skins for 2018 as well as a quota of 5 trophy hunting (Isberg et al., 2019).

A ranching program for Crocodylus niloticus was implemented in Ethiopia in 1985 when the government created Arba Minch Crocodile Ranch (AMCR) (Shirley et al., 2014). The mortality rate of Crocodylus niloticus at AMCR of hatchlings collected from wild have a very high mortality rate up to $67.9 \%$ basically from hatchlings, 1-year-old, and juveniles (Whitaker, 2007; Shirley et al., 2014). Main factors affecting the production management of Crocodylus niloticus and health-related problems that decrease the number (number of mature individuals are 50,000-70,000). Some of the lives threatening factors of Nile crocodiles are urban sprawl, environmental pollution, and habitat destruction, subsistence agriculture and deforestation, and diseases (Isberg et al., 2019).

The Crocodiles in AMCR were provided mainly with feed items like fish and meat. The pathological finding was most frequently arise from nutritional deficiency as a result of crocodiles being fed meat meal, such as frozen fish and frozen meat without a bone meal. There is known to be deficient in important minerals and vitamins (Gilber, 2000). Skin lesions were the second most common problems observed at AMCR after paralysis of hind legs (Shirley et al., 2014). Therefore, this was prepared to review the major diseases and management status of Crocodylus niloticus in Arba Minch ranches, Ethiopia.

\section{Husbandry and breeding of Nile crocodile}

Understanding the habitat requirements and habitat use of a specific Nile crocodile population requires a combination of understanding the specific landscape mosaic dynamics that the population is found in and the resource requirements of the selected Nile crocodile (Champion and Downs, 2015). Its presence and absence also depend on the climatic conditions and the environment i.e. the landscape to basking and feed (Botha et al., 2011). In farm situations, the basic requirements for the well-being of farm crocodiles include ensuring that: 1 . appropriate and sufficient food and water are provided to sustain health and vitality; 2. sufficient area is provided to maintain well-being and to allow crocodiles to exhibit normal behavior; 3 . they are protected from predation; 4 . they are protected from disease, including disease that can be exacerbated by management practices; 5 . they are protected from extremes of climate, particularly during certain phases of their lives; and 6. pain, distress, suffering, and injury are minimized or avoided (Anon, 1992; Tosun, 2013). The mean body temperature of a crocodile is $25.6^{\circ} \mathrm{C}$ and a range of 6 degrees, with fluctuations from the mean of -2.6 to $+4^{\circ} \mathrm{C}$. Under optimum raising conditions, with adequate temperatures, hatchlings have high metabolic rates, high food requirements, and they grow rapidly; in countries with "cold" winters (e.g. USA), crocodilians are grown very successfully in heated sheds, but not all species appear to require or can tolerate high and constant temperatures. Some require a mosaic of temperatures, where they can spend part of, rather than the whole day with body temperatures in the $30-33^{\circ} \mathrm{C}$ range (Manolis and Webb, 2016).

\section{Ranching Nile crocodiles}

Ranching is a commercially viable strategy for crocodile farming which is widely used and demonstrates accepted conservation advantages. Ranching entails harvesting crocodile eggs from wild and incubating them to produce hatchlings (Khosa et al., 2012) it can also include the harvesting of hatchlings immediately post-hatching. The collections of eggs, hatchlings, and juveniles from the wild give natural populations a conspicuous economic value (Luxmoore, 1992; Thorbjarnarson et al., 1992; Whitaker, 2007). In Ethiopia, there are two Crocodile ranches, the State-owned Arba Minich Crocodile Ranch (AMCR) and the privately owned, Blen Development PLC, AMCR was created at the mid of 1984 and Blen was created in the mid of 2006 (Whitaker, 2007; Mahammed, 2008).

\section{Food and feeding behavior of Nile crocodile}

Crocodylus niloticus has a similar ontogenetic shift in diet to that of other crocodilians (Wallace and Leslie, 2008). The powerful enzymatic digestive juices of crocodiles completely digest bones, hooves, and feathers but being poikilothermic animals, digestion is promoted by higher temperatures. Juveniles feed on insects, spiders, snails, gastropods, and mussels in the shallows and onshore. Young crocodiles feed mostly on toads, frogs, and small fish such as Clarias, Labeo, and Tilapia species (Whitaker, 2007; Furstenburg, 2008). With age the diet changes to catfish (barbel) and larger mammals up to the size of young giraffe, buffalo, and elephant. On average catfish comprises $70 \%$ of the diet of adult Nile crocodile. During summer a $4 \mathrm{~m}$ adult will consume a large meal once in 2-3 weeks. Sub-adults of $1.5 \mathrm{~m}$ eat once a week while juveniles feed daily. Carrion is taken only when fresh food is not available. It is estimated that up to $60 \%$ of the food intake is converted to fat for storage in the tail and trunk (Bolton, 1997; Johan and Frits, 2000; Davis, 2001; Furstenburg, 2008).

\section{Reproduction in Nile crocodiles}

Copulation takes place in water and all species lay eggs (Bolton, 1997). Reproductive females had a plasma testosterone surge corresponding to the time of courtship and mating. Both reproductive and non-reproductive females showed increased plasma progesterone at several times of the year (Kofron, 1990). Courtship and mating occurred in water during the day, usually directly in front of the shared basking ground (Kofron, 1991). Gender assessment in crocodilians is typically achieved by digital examination of the cranio-ventral cloaca; males have a penis while females have a clitoris. The penis may be exteriorized for visual examination if there is doubt on palpation. Adult male crocodilians typically grow to a larger size than females (Pooley, 1982; Kofron, 1991; Timothy, 2018). In Ethiopia the mating period for 
Nile crocodiles is September/October, nesting occurs in the dry season of December/January, and hatchling occurs at the onset of the rainy season of March/April months. Range and average clutch size are 25-70 eggs; average: with an average size of $\mathbf{4 5}$ for Lake Chamo, in the south of Ethiopia. Clutch size increases and is directly proportional to female size and age, with average fertility rates for first nesters 20 to $50 \%$, increasing to 80 to $90 \%$ for older and mature females (Whitaker, 2007).

\section{Normal health conditions of Nile crocodiles}

Husbandry techniques are continually evolving to ensure animals are maintained in good health. There are major approaches to assessing the normal health status of crocodiles in ranches; anatomical and physiological assumptions, health correlations such as body condition, growth rates, and size, survival rates (Isberg et al., 2009), Frequency of injuries, disease incidence, parasite incidence, reproductive performance; biochemical Indicators (such as comparative corticosterone levels, which are an indicator of stress) (Elsey et al., 1990a,b; Turton et al., 1997; Franklin et al., 2003; Isberg et al., 2009, 2013; Finger et al., 2015); behavioral observation and stimulus-response. Over and above genuine concerns about animal welfare, the media is often used to promote information that is deliberate manipulation of factual evidence (Manolis and Webb, 2016). Husbandry strategies for different ages and sizes of crocodilians have evolved separately in different farms and for different species; however, some fundamental principles can be applied to most, if not all, species. General considerations like suitable incubation and hatchling characterize, initiation of hatchling feeding, treatment of hatchlings, nutritional deficiencies and imbalances, metabolic rate and temperature, water quality, effects of hatchling size on growth, effects of sex on growth, density and social behavior (Huchzermeyer, 2003).

\section{Economic importance of rearing Crocodylus niloticus}

Over the past five decades, the captive rearing and managed harvests of crocodilians have been held up as a success story in the search for balanced, sustainable use of wildlife and the generation of wildlife products for international trade (Thorbjarnarson, 1999). Wild animals and their derivatives are traded worldwide to meet demands for food, clothing, decorative items, traditional medicines, and pets (Challander et al., 2015). The overall volume of world trade in classic crocodilian and caiman skins has been variable over the 10 years 2007 to 2016, with an average of 1.44 million skins exported annually. Over the period 2007-2016, an average of 201,000 Crocodylus niloticus skins were exported globally per year, with an increasing trend over the period 2009-2016 (Caldwell, 2018). In 2016, Zambia was the leading (112,434 Crocodile skins) exporter of Nile crocodile skins to the global market. Data provided by Ethiopian Wildlife Conservation Authority (EWCA), show that Ethiopia, exported 594, 492, 77, and 400 Crocodile skins in 2007, 2008, 2011, and 2012, respectively. The country's crocodile skin export capacity is declined due to international market in the years 2010, 2015, and 2016 to 4, 6 and 7 skins, respectively and as the report shows there was Zero export of skin in the years 2009, 2013 and 2014 (Caldwell, 2018). In 2017, Crocodile hatchlings can be sold at USD 2 each to foreign investors, 15 birrs (USD 0.75) to Ethiopian investors, and 5 birrs (USD 0.25) to farmers for quantities over 100. Crocodile eggs are sold at half those prices. The Nile crocodile is also hunted by foreign tourist hunters for a USD 2000 trophy fee (Whitaker, 2007; Shirley et al., 2014; Nisagurwe, 2017). Crocodiles are not only involved in the skin trade but also traded as live animals as crocodile meat and for their teeth (Caldwell, 2018).

\section{Constraints to Nile crocodile management}

Crocodile ranch management in Ethiopia requires a formal management plan in terms of national legislation. The species is currently subject to both consumptive (e.g., ranching and trophy hunting) and non-consumptive (e.g., tourism) uses, as well as implicated in human-wildlife conflict. Crocodiles are theoretically managed by federal, state, zonal, and woreda (district) administrations under national laws for biodiversity protection and utilization, ranching, and trophy hunting. A formal management plan should also provide a framework for overcoming some current management deficiencies but this is not yet the case, in Ethiopia (Whitaker, 2007; Shirley et al., 2014). Local threats for crocodile conservation management includes; (a) lack of regulation enforcement, (b) illegal fishing gear and unsustainable growth of the fishing industry, which has resulted in overfishing, a decline in a population of the main target species to almost non-viable levels and the apparent extinction of one of them; (c) increase in cattle grazing such that many areas previously used by crocodiles for basking and nesting have been destroyed. (d) Cultivation up to the lakeshore which is impacting negatively on crocodile behavior, recruitment, and survival. Droughts due to climate change and other effects will likely increase this threat (Whitaker, 2007). In addition to management problems in the wild, Nile crocodiles are suffering from nutritional abnormalities and health problems at AMCR. The main health problems are a combination of mal-nutritional diseases and skin diseases. The mortality rate of almost $70 \%$ of hatchlings and juveniles has been ascribed to nutritional bone diseases caused by continuous feeding of meat and fresh frozen fish meat. AMCR harvested more than 8890 crocodile skins from 1982-1998 E.C, they would earn more than USD 3,744,000.00 if they harvest first-grade skin, but the reality is 769,000 ETB (USD 1 was 8 ETB when the author reports the data) (Shirley et al., 2014).

\section{Common diseases of Nile crocodiles}

According to Radostits et al. (2006) definition of animal diseases, crocodile diseases are 'inability to perform physiological functions at normal levels even though nutrition and other environmental requirements are provided at adequate levels'. The diseases of Nile crocodiles are classified as infectious (transmissible) and non-infectious (non- 
transmissible). A transmissible crocodile disease includes bacterial, viral, fungal, protozoan, and parasitic diseases; the rest are nutritional, toxic poisonings and metabolic disorders are non-transmissible crocodile diseases (Huchzermeyer, 2003).

\section{Infectious diseases of Nile crocodile}

Ippen and Zwart (1996) postulated as the most reptiles in captivity were taken from the wild. Their infectious and parasitic diseases will have been imported with them, and that husbandry practices would have an influence on disease outbreaks there are several crocodile-specific viral and bacterial infections, some of which may even be species or genus specific. However, their present distribution may also be due purely to geographical limits. The specificity of parasites also varies. Besides, there are many non-specific infections, particularly bacterial and fungal (Huchzermeyer, 2003).

\section{Bacterial infections}

Only a few bacteria cause specific diseases in crocodiles, and even fewer of these are crocodile-specific. However, many different species of bacteria can cause nonspecific septicaemias. These bacteria are recruited either from the aquatic environment, the intestinal flora or from food contaminants, particularly where raw meat is used as feed. All septicaemias, specific and non-specific, are triggered, if not caused, by stress. Bacteria are allowed to escape under severe stress from the intestine into the blood circulation, and if the stress continues, the resultant immune suppression prevents the crocodile from overcoming the initial escape and allows the bacteria to gain a foothold (Huchzermeyer and Cooper, 2000). Some bacterial genera that cause infection in Crocodiles are included in this review.

\section{Mycoplasmosis}

Mycoplasmas were isolated from lungs and synovial fluid of the Nile crocodiles and the isolates were identified as Mycoplasma crocodyli (Kirchhoff et al., 1997). The joints of infected crocodiles were had swollen joints and filled with excessive quantities of turbid fluid, in chronic cases with dry fibrinous exudate, and some of the animals were found to have lesions of pneumonia. As $M$. crocodyli is a relatively recently described (in Zimbabwe in 1995) pathogen, aspects of other Mycoplasma spp. (Mohan et al., 1995). M. crocodyli, as with other Mycoplasmas, lacks true cell walls and has a typical fried-egg appearance on solid medium, but grows relatively well in an artificial medium. Glucose and mannose are both fermented, and cholesterol or serum is required for growth. It is one of the few Mycoplasma spp. that fulfills Koch's postulates for disease causation (Kirchhoff et al., 1997). Serological assays are often used to test animals for exposure to infectious agents and include many of the common laboratory procedures such as the ELISA, agglutination, precipitation, neutralization, etc. Indirect ELISA (iELISA) for the detection of antibodies (Ab) to $M$. crocodyli infection in crocodile sera was developed using Ag and anti-crocodile conjugate (Dawo and Mohan, 2007). An immune-blotting protocol for the detection of antibodies to Mycoplasma crocodyli was developed using the sonicated antigen of the reference strain 266/93. Immunoblotting detected nine reacting antigens, of which the 33 and $40 \mathrm{kDa}$ antigens were immune-dominant (Dawo and Mohan, 2008). The complete genome sequence of $M$. crocodyli has recently been reported but, although at least five potential virulence factors have been identified, their role and significance are still unclear (Brown et al., 2011), polyarthritis is the best described clinical and pathological sign including progressive weakness, ranging from stiffness to complete immobility. Different stages of exudative polyarthritis are encountered at necropsy, ranging from turbid mucous containing Mycoplasma spp. in acute and sub-acute cases, to yellow, inspissated exudates in chronic cases. Histopathological changes include inflammatory edema of the surrounding tissue, necrosis of the superficial layers of the synovial membrane, and fibrin deposition, lymphocytic infiltration, and fibrosis of the joint capsule. Apart from polyarthritis, the organism also triggers pneumonia, histo-pathologically characterized by consolidation and edema of affected areas, with a white blood cell (particularly poly-morpho-nuclear cells and mononuclear cells) and erythrocyte infiltration (Mohan et al., 1995; Kirchhoff et al., 1997; Huchzermeyer and Cooper, 2000; Huchzermeyer, 2003).

In general, mycoplasmosis control can be divided into three important sectors, namely vaccination, medication, and keeping disease-free animals (Desrosiers, 2001; Ley, 2006; Caswell and Archambault, 2008; Kleven, 2008). These are generally not mutually exclusive and are used in combination as required. Medication, including parenteral treatment of diseased crocodiles and/or in-feed treatment, have been performed during crocodile mycoplasmosis outbreaks, but treatment failures (Mohan et al., 2002), reports on antimicrobial resistance (Ayling et al., 2000, Reinhardt et al., 2002, Rosenbusch et al., 2005, Antunes et al., 2007) and high costs eliminates this as a long term control strategy (Grobler, 2013). Vaccination against mycoplasmosis is widely used in commercial pig, poultry, and cattle production systems, particularly in multi-age set-ups because it often is the only viable long-term option. Both inactivated and live-attenuated vaccines have been tested and are currently in use (Grobler, 2013).

\section{Chlamydiosis}

Chlamydiosis is a disease in farmed Nile crocodiles caused by chlamydiae closely related to Chlamydia psittaci, but probably a different species. There are two forms: acute hepatitis and chronic conjunctivitis (Huchzermeyer et al., 1994). On post-mortem examination, the liver is found to be pale, mottled, and enlarged and the spleen slightly enlarged. There are mild ascites and a severe hydro-pericardium: the most severe histopathological changes are found in the liver: a severe portal to diffuse lymphoplasmacytic hepatitis with congestion, mild bile duct proliferation, vacuolar degeneration of the hepatocytes and multifocal to coalescing necrosis. Numerous colonies of intra-cytoplasmic organisms are present in the hepatocytes (Huchzermeyer, 2003). The mode of transmission is not identified, yet. But the contamination of surface water by wild carrier crocodiles is suspected. The diagnosis is based on the demonstration of the agents either microscopically or by culture (Huchzermeyer, 2002). An investigation into the cause of acute mortality in the farmed 
hatchling, Crocodylus niloticus led to the isolation of chlamydia from the livers of affected animals (Huchzermeyer et al., 1994). Both forms of chlamydiosis respond to tetracycline (Huchzermeyer, 2002); Terramycin soluble powder (10g/kg of feed), or pure oxytetracycline $(1 \mathrm{~g} / \mathrm{kg}$ of feed) (Huchzermeyer, 2003). The prevention of chlamydiosis must be based on stress prevention as well as on strict hygienic measures, such as the use of borehole or well water in the rearing section, as well as the disinfection of footwear when moving from section to section (Huchzermeyer, 2002; 2003).

\section{Salmonellosis}

Salmonellosis is caused by bacteria of the genus Salmonella and manifests itself either as enteritis, particularly in hatchlings (Huchzermeyer, 2003). Reptiles may be considered a natural reservoir for Salmonella bacteria, but except for pet turtles, the role of poikilothermic vertebrates in the transmission of Salmonella to other animals and men is common (Madsen, 1996). From 1985-1994 scientists, Huchzermeyer and Agnagna were isolated Salmonella from 148 out of 173 from farmed Nile crocodiles (Huchzermeyer, and Agnagna, 1994; Walt et al., 1997). A study from Zimbabwe published that the prevalence of Salmonella was $30 \%$ in fresh and $20 \%$ in the frozen meat samples (Madsen, 1996), but the prevalence of the bacteria has not been adequately studied. Bacterial septicemia is often precipitated by severe stress with frequent change in temperature, the ongoing infection may cause depression and anorexia, the enteritic form of the disease may either cause fibrinous exudation and occlusion of the intestine, or diarrhea, hemorrhagic enteritis due to $S$. choleraesuis (Ocholi and Enurah, 1989; Huchzermeyer, 2003). Diagnostic procedures are performed by bacterial culture of blood, feces, or synovial aspirate. The treatment of clinical cases comprises oral or parenteral administration of an antibiotic selected by an antibiogram and the elimination of the precipitating stressor(s). The prevention methods require strict sanitary feed, hygiene, washing with a detergent to remove protective layers of fat, and vaccinating via a calf paratyphoid vaccine (Huchzermeyer, 2003).

\section{Non-specific septicaemias}

The non-specific septicaemias of crocodiles are caused by a large variety of bacteria of enteric or environmental origin, many of which are opportunistic rather than obligatory pathogens, mostly part of the normal intestinal flora, although the intestinal flora of farmed crocodiles may be modified by antibacterial treatments and the introduction of potential pathogens when feeding meat, particularly from farm mortalities (Huchzermeyer, 2003). Septic wounds rarely lead to septicaemias and this adds support to the hypothesis of the enteric origin of septicemia in crocodiles (Huchzermeyer and Cooper, 2000). Some of the isolated cases of septicaemias in Nile crocodiles (Table 1). The course of the disease depends on the environmental temperature (the course is fast in hatchlings kept at $32-34^{\circ} \mathrm{C}$, but slows in juveniles at low temperatures, while it can take several months in adults) and the size of the affected crocodiles. In some chronic cases, the affected crocodiles develop white patches around the nostrils and eyes, as well as on the dorsal surface of the body and limbs. In advanced cases, the likelihood of a treatment being successful is minimal. For the prevention of septicaemias, it is necessary to maintain optimal temperature (Huchzermeyer, 2003).

\section{Table 1 - Isolated cases of septicaemias in Nile crocodiles}

\begin{tabular}{lcc} 
Septicaemic agents & Reported author/s & Reported Year/s \\
\hline Aeromonas hydrophila and A. shigelloides & Foggin & 1992 \\
Citrobacter spp. and C. freundii & Foggin & 1992 \\
Corynebacterium spp. and C. pyogenes & Foggin & 1992 \\
Enterobacter agglomerans & Foggin & 1992 \\
Escherichia coli & Foggin & 1992 \\
Providencia rettgeri & Foggin & 1992 \\
Pseudomonas spp. and P. aeruginosa & Foggin & 1992 \\
Pasteurella multocida & Dziva and Mohan \\
Source: Huchzermeyer and Van Wyk (2003) & 2000
\end{tabular}

\section{Viral Diseases of Nile crocodiles}

The etiology of reptilian viral diseases can be attributed to a wide range of viruses occurring across different genera and families. Forty to fifty years ago, studies of viruses in reptiles focused mainly on the zoonotic potential of arboviruses in reptiles and much effort went into surveys and challenge trials of a range of reptiles (Ariel, 2011). The diagnosis of viral infections should be based on the presence of serological tests and the isolation and characterization of the virus. Regarding the crocodile viruses, there is a serious problem. None of them can be isolated in embryonated chicken eggs, the most common tool in veterinary virology laboratories, nor can they be grown in any of the cell culture lines presently in use. Nobody has yet isolated or established crocodile embryonic cell lines that could be used for this work (Huchzermeyer, 2003).

\section{Adenoviral infection}

These viral infections most commonly affect the liver of hatchlings under 5 months, less often the intestines and pancreas, and sometimes the lungs as well, but rarely all at the same animal (Jacobson et al., 1984; Foggin, 1987; 1992). Diagnosis of adenovirus is now largely done by molecular tools such as PCR directly on swabs or organs followed by 
sequencing (Wellehan et al., 2004), or in situ hybridization of formalin-fixed tissues (Perkins et al., 2001), or by transmission electron microscopy in negatively stained feces of three Nile crocodile (Huchzermeyer et al., 1994). Apart from its indirect diagnosis, there is no reported successful isolation of the crocodile adenovirus virus (Huchzermeyer, 2003). Lethargy and anorexia are the only clinical symptoms associated with a massive mortality rate (Foggin, 1987). On post-mortem diagnosis, there may be slight icterus, swollen and pale liver, and pale yellow bile; swollen and pale intestines sometimes filled with fibrous exudate (Jacobson et al., 1984; Foggin, 1992). Repeated findings in chronic hepatitis are fibrosis of the portal tracts and bile duct hyperplasia (Foggin, 1992). Since there is no specific treatment for adenoviral infections secondary antibiotic drugs are administered infections may have a beneficial effect in serious outbreaks. Prevention should be based on strict hygienic measures aimed at preventing the horizontal spread of the virus, including not using water from rivers inhabited by wild crocodiles, and preventing stress, particularly thermal stress caused by wide temperature fluctuations in open-air rearing pens in winter (Huchzermeyer, 2003).

\section{Parapoxvirus infection}

Crocodile pox (Afonso et al., 2006; Huchzermeyer et al., 2009) is an infection of hatchling and juvenile crocodiles with a Parapoxvirus, characterized by brown crusty lesions (Pandey et al., 1990) in the oral cavity, on the head and the ventral (Marschang, 2011) and lateral surfaces of the body and tail (Foggin, 1987; Horner, 1988; Huchzermeyer et al., 1991; Buoro, 1992). Lesions on the eyelids may cause blindness, and lesions on the head may cause a shrinking of the skin, leading to deformities (Foggin, 1987; Horner, 1988). The skin lesions appeared as dark brown, crusty pox-like lesions up to $3 \mathrm{~mm}$ in diameter, with a sharply outlined central depression. The lesions are situated between the scales and can occur over the entire body. They intended to be concentrated mainly on the ventral and lateral surfaces of the body and tail, the upper and lower surfaces of the limbs, and around the jaws and eyes (Huchzermeyer et al., 1991). It is presumed that the virus can be carried and shed by clinically healthy carriers. Adult breeding stock on the farm also is a possible source of the virus. While the virus could possibly be transmitted by mosquito bite, it is much more likely to be transmitted by contaminated water, or the acquisition of hatchlings from a farm where the disease had occurred (Horner, 1988; Huchzermeyer et al., 1991; Huchzermeyer, 2003). There is no specific treatment against crocodile pox infection (Huchzermeyer, 2003), A crude autogenous vaccine prepared from scabs from affected animals reduced the recovery time (Horner, 1988), but there is the danger of causing generalized infection amongst unvaccinated individuals, when the live vaccine virus is introduced into the rearing environment (Foggin, 1992). The prevention of crocodile pox infection is based on avoiding the use of potentially contaminated water and the avoidance of stress, particularly heat stress (Huchzermeyer, 2003)

\section{Other viral infections}

Other viruses found in Crocodylus niloticus, with less economic importance, include Coronavirus-like particles (found by transmission electron microscopy in negatively stained feces of four 2-3-year-old crocodiles at a farm with severe mortality in that age group; Filamentous forms of influenza $\mathrm{C}$ virus (found by transmission electron microscopy in negatively stained feces of eight Nile crocodiles (length $31-81 \mathrm{~cm}$ ) from one farm associated with high mortality over 1 month (Huchzermeyer et al., 1994); Newcastle disease virus, although it does not cause clinical disease in crocodiles. But, when Nile crocodiles are fed fowl that had died from Newcastle disease, they seroconvert; Paramyxovirus was found in the feces of a single crocodile from a farm where no poultry had been fed (Thomson, 1972; Huchzermeyer et al., 1994; Pfitzer et al., 2000).

\section{Parasitic diseases of Nile crocodile}

Nile crocodiles are infected by many ecto and endo-parasites, with trypanosome being the most common. The trypanosomes of crocodiles are harmless flagellate blood parasites transmitted by biting flies and possibly also mosquitoes (Hoare, 1928; 1929; 1931). Other blood parasites that have been isolated from Nile crocodiles are Hepatozoon species such as Hepatozoon petite and Hepatozoon sheppardi (Travassos Santos Dias, 1952). Coccidiosis in Nile crocodiles is caused by a complicated parasitic protozoan and several coccidian parasites of crocodiles have been described from fecal suspensions according to their oocyst morphology such as Eimeria spp. (Hoare, 1932; Huchzermeyer, 2003), Goussia spp. (Gardiner et al., 1986) and Cryptosporidia (Siam et al., 1994; Lane and Mader, 1996) (Table 2). The pentastomid parasites of chelonians and crocodilians are currently divided into the family Sebekidae and Subtriquetridae (Riley et al., 1990; Riley 1994; Riley and Huchzermeyer 1996; Riley et al., 1997; Junker and Bookmker, 2006; Junker et al., 2016). Pentastome assemblages comprised seven species in three Sebekid genera, Alofia Leiperia, and Sebekia, for example, Alofia nilotici (Riley and Huchzermeyer, 1995), A. simpsoni (Riley, 1994), Leiperia cincinnalis (Sambon, 1922), Sebekia cesarisi (Giglioli, 1922), S. minor (Junker et al., 1998; 2016) and S. okavangoensis (Riley and Huchzermeyer, 1995), Subtriquetra rileyi (Junker et al., 1998).

In the lungs, the parasites suck blood and thereby can cause infection and inflammation. In cases of stress septicemia, the bacteria present in the blood can invade the lung tissue in the lesions caused by the pentastomes, and thus create the abscesses found associated with pentastome infestations. In severe infestations, pentastome eggs may be found in the host's feces. On post-mortem examination, the parasites are found in the larger air passages of the lungs. The treatment requires antiparasitic Dectomax $®$ (Doramectin 1\%) dose of $1 \mathrm{ml}$ per $50 \mathrm{~kg}$ of body mass, while Ivermectin at effective doses is toxic. For prevention, it is vital to control the fresh fish food as a fish are intermediate hosts, and distress prevents Nile crocodiles from forming lung abscess (Huchzermeyer, 2003). 
Table 2 - Major parasitic agents of the Nile crocodile

\begin{tabular}{|c|c|c|c|}
\hline Endoparasites & Genus and species & Authors & Reported years \\
\hline \multirow{12}{*}{ Ascaridoids } & Dujardinascaris dujardini & Bayliss & 1947 \\
\hline & Dujardinascaris gedoelsti & Sprent & 1977 \\
\hline & Dujardinascaris madagascariensis & Sprent & 1977 \\
\hline & Dujardinascaris puylaerti & Sprent & 1977 \\
\hline & Dujardinascaris tasmani & Ortlepp & 1932 \\
\hline & Gedoelstascaris vandenbrandeni & Sprent & 1978 \\
\hline & Hartwichia rousseloti & Sprent & 1983 \\
\hline & Multicaecum agile & Sprent & 1983 \\
\hline & Ortleppascaris nigra & Graber & 1981 \\
\hline & Terranova crocodile & Machida et al. & 1992 \\
\hline & Trispiculascaris assymmetrica & Sprent & 1983 \\
\hline & Trispiculascaris trispiculascaris & Sprent & 1983 \\
\hline Capillarioids & Paratrichosoma spp. & Foggin & 1987 \\
\hline Trichinellae & Trichinella spiralis & Mukaratirwa and Foggin & 1999 \\
\hline \multirow{2}{*}{ Filariae } & Micropleura vivipara & Foggin & 1987 \\
\hline & Oswaldofilaria versterae & Bain et al. & 1982 \\
\hline \multirow{13}{*}{ Trematodes } & Acanthostomum productum & Hughes et al. & 1941 \\
\hline & Acanthostomum vicinum & Hughes et al. & 1941 \\
\hline & Allechinostomum crocodile & Hughes et al. & 1941 \\
\hline & Cyatocotyle fraternae (fraterna?) & Bisseru & 1957 \\
\hline & Neoparadiplostomum kafuensis & Bisseru & 1956 \\
\hline & Neoparadiplostomum magnitesticulatum & Bisseru & 1956 \\
\hline & Neoparadiplostomum africana & Bisseru & 1956 \\
\hline & Neoparadiplostomum leiperi & Bisseru & 1956 \\
\hline & Nephrocephalus sessilis & Hughes et al. & 1941 \\
\hline & Prostrigea arcuata & Bisseru & 1956 \\
\hline & Pseudoneodiplostomum bifurcatum & Huchzermeyer and Agnagna & 1994 \\
\hline & Stephanoprora ornate & Hughes et al. & 1941 \\
\hline & Exotidendrium spp. & Foggin & 1992 \\
\hline
\end{tabular}

\section{Fungal Infections in Nile crocodiles}

Crocodiles are farmed mainly for their skin, and most fungal infections are affecting the skin of Nile crocodiles (in both farms and wild). Many of the fungi involved in these infections are part of the normal intestinal flora and are excreted daily with the feces into the water (Huchzermeyer, 2003). Normally, the fungi are inhibited in the intestine by the bacterial flora. If the latter is suppressed by prolonged antibacterial treatment, the fungi can multiply more freely. Reported cases of most fungal diseases were diagnosed by histopathological examinations of the host tissue (Gilber, 2000). The tissue reaction to fungal infections is granulomatous and not exudative as it is in most localized bacterial infections. The granulomata are characterized by the presence of multinucleated giant cells (Huchzermeyer, 2003). Beauveria bassiana (Keymer, 1974) has been isolated from the lungs of captive Nile crocodiles and Trichosporon species has been isolated from the tongue and gingivae of a captive Nile crocodile (Kuttin et al., 1978). Systemic and respiratory infections are often diagnosed too late for treatment to be considered, Oral mycosis and gastro-intestinal mycosis are treated with antifungal injections, whilst skin dermatophytes are treated by injections and topical routine of administration. Avoiding excessive fungal build up prevents the diseases and an aggressive antibiotic also delays the development of fungus (Huchzermeyer, 2003).

\section{Non-infectious diseases of Nile crocodiles}

Captive crocodiles frequently are given a monotonous diet, which may be deficient in one or more essential constituents. This may lead to deficiencies of certain minerals and vitamins that used for fast growth rate, and this can further accentuate potential imbalances in their artificial nutrition. These also enhance some conditions like osteomalacia, rickets, secondary hyperparathyroidism, metabolic bone disease, fibrous osteodystrophy and osteoporosis, diaphanous teeth, Vitamins deficiencies (Vitamins A, B, C, D, E, and K), mineral deficiencies ( $\mathrm{Ca}^{++}, \mathrm{K}^{+}, \mathrm{P}$ and $\mathrm{Zn}$ ), and hypoproteinaemia. Poisoning occurs not only through the deliberate or accidental ingestion of substances but also human activities such as organophosphates poisoning from pesticides, algicides, algal toxicity, rodenticides, radionucloides, and fire ants delays the production of Nile crocodiles (Huchzermeyer, 2003). 


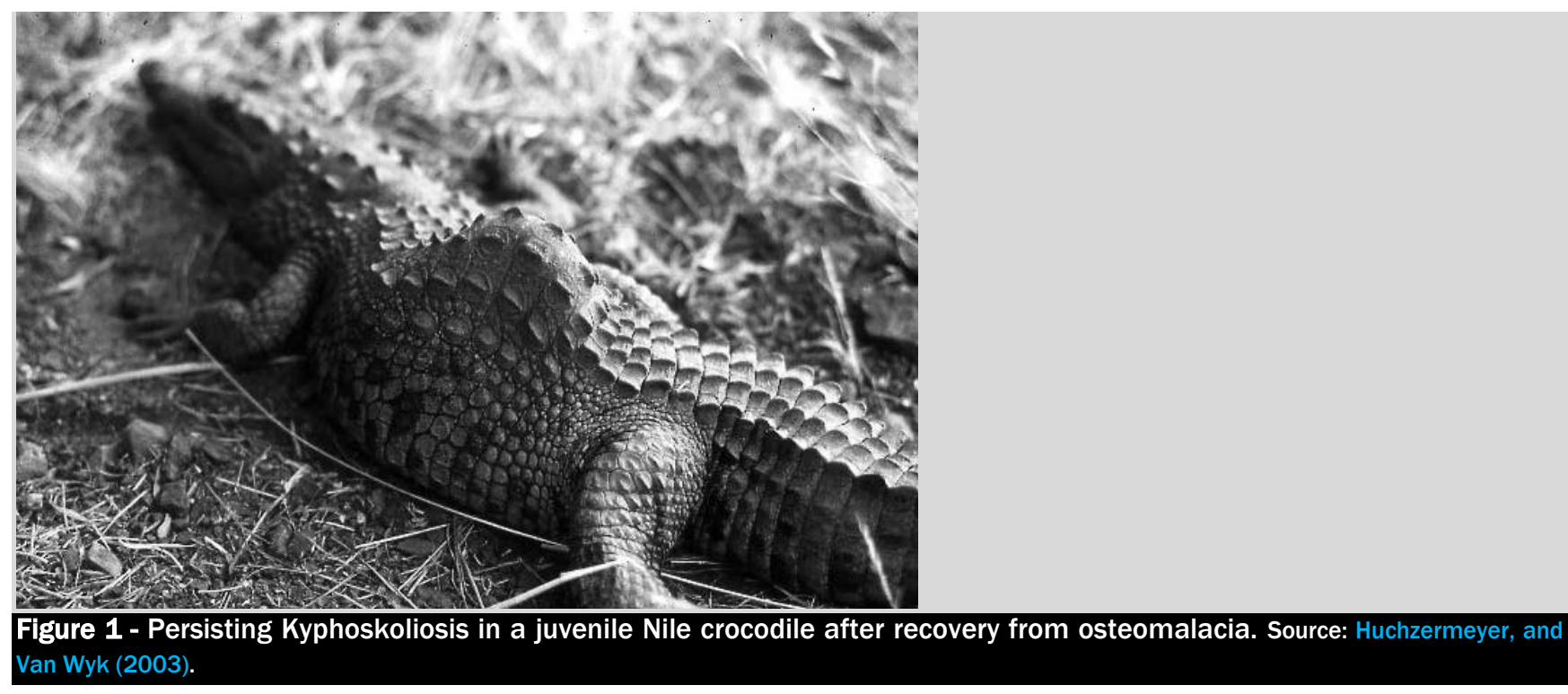

\section{CROCODILE DISEASES AT ARBA MINCH CROCODILES RANCH, ETHIOPIA.}

Arba Minch Crocodile Ranch (AMCR) is found in Arba Minch, where it is located $500 \mathrm{~km}$ south of Addis Ababa with an altitude range from 1100-2800 $\mathrm{m}$ above sea level. Arba Minch district covers 173,108 hectares and has three climatic zones; lowland (37.5\%), midland (40.5\%) and highland $(22 \%)$ areas with an average mean temperature range of $15^{\circ}-31^{\circ}$ C. The area has grasses, bushlands and deciduous forests with sandy and clay soil type (Kebede, 2006). In order to conserve and optimally utilize the Nile crocodile ranch was established in 1984 (Yeshdenber, 1994; Graham and Gebre, 1997; Kebede, 2006; Whitaker, 2007; Shirley et al., 2014).

Although crocodile ranching practiced in Ethiopia, for almost 35 years, it is difficult to find any work on health problems of crocodiles and management activities. The government of Ethiopia collaborated with CSG to study the crocodile ranching in the country and highlighted the documents housed at EWCA that focused mainly on surveys and conservation issues. Mahammed (2008) researched crocodile health at AMCR but his report remains unavailable. In his cross-sectional study, no parasites or their ova were found ( $n=80 ; 60$ Juvenile and 20 Adults). Clinical investigation of the same animals showed 20/80 abnormalities, predominantly hind legs, and skin lesions.

The clinical assessment of the previous study $25 \%$ (20 out of 80 ) had clinical abnormalities; 5 of the crocodiles were unable to move on dry land during basking, showing paralysis of two hind legs and slight swelling of the tail muscle, and yet were able to swim 'normally'. A further 5 animals showed multiple skin lesions, 5 showed circling movement while swimming in the water, and the remaining animals were dead before the examination. During post mortem examination, there was excessive yellow and hard fatty accumulation was identified in tail muscles. $6.25 \%$ (5 out of 80 ) had multiple skin lesions which were multiple and dominated by small erosions, on the ventral aspect of the abdomen and One crocodile showed ulcerative types of skin lesion over its head, neck, back, and tails. The sick crocodiles were found dead after 2-4 weeks. And showed accumulation of fluid in the pericardial sac slightly enlarged pale heart and liver. Most of these problems were observed on juveniles (young) and yearlings and occurred after they were provided with frozen fish meat (Mahammed, 2008).

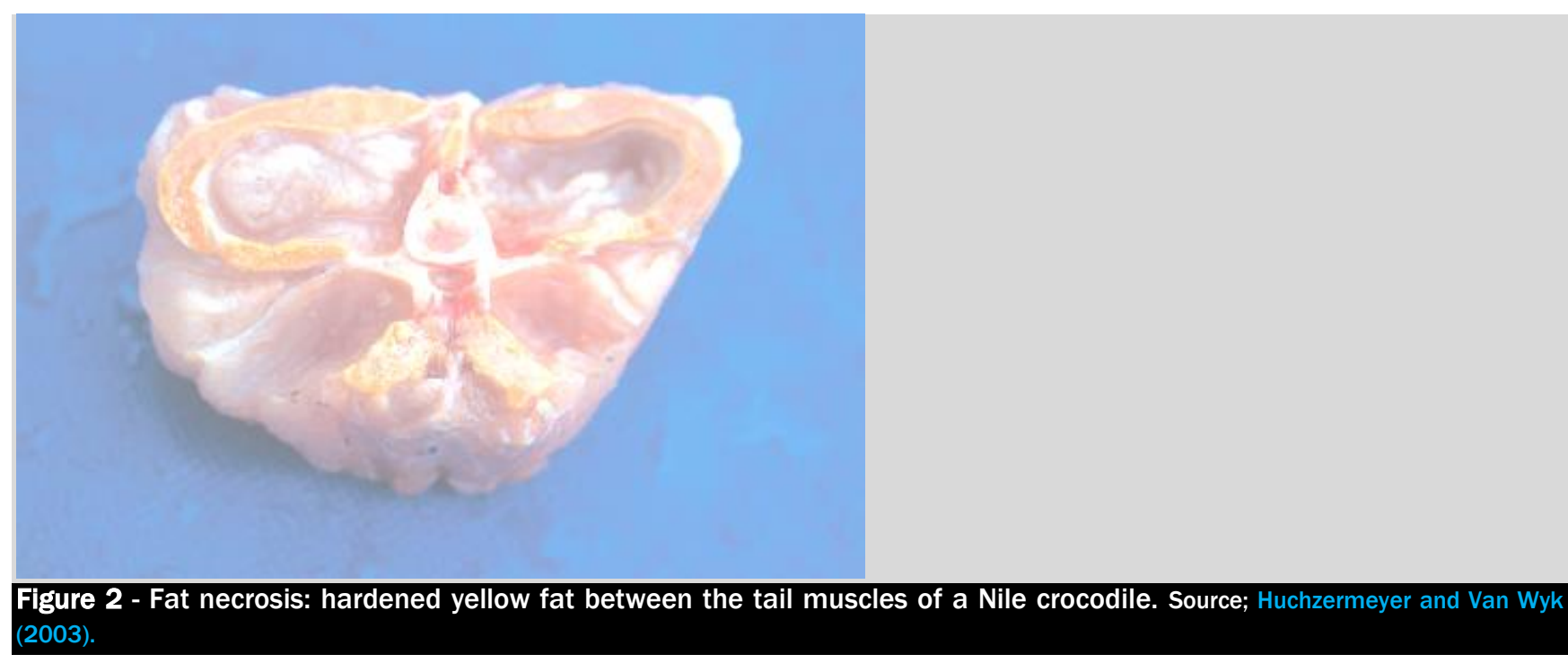




\section{Nutritional Diseases of Nile crocodiles in AMCR}

Nutritional bone disease is an umbrella term that covers a range of related conditions and names, such as osteomalacia, rickets, metabolic bone disease, fibrous osteodystrophy, and osteoporosis. Metabolic bone disease shifts the emphasis on calcium ( $\mathrm{Ca}$ ) and phosphorus $(\mathrm{P})$ metabolism. Osteo-malacia and fibrous osteodystrophy are the terms for the condition in young hatchlings where their bones fail to harden due to the lack of calcium. Rickets applies to malformations of the growing bone when due to the lack of vitamin $D_{3}$, the bones also fail to harden and become bent. Osteoporosis occurs in older juveniles and adults, where the already hardened bone structure becomes weakened by the withdrawal of calcium for metabolic needs (Huchzermeyer, 2003). The Crocodiles in AMCR were provided mainly with feed items like fish and meat. The meat that was used as a feed for crocodiles includes meat from dead old horses, donkeys, dogs, cattle, sheep, goats, and crocodiles themselves. The crocodiles are fed three times per week or once every two days while they were young. The pathological finding was most frequently arising from nutritional deficiency as a result of crocodiles being fed meat meals, such as frozen fish and frozen meat without a bone meal (Mahammed, 2008). There is known to be deficient in important minerals and vitamins (Gilber, 2000).

Feeding frozen fish has two limitations; the first is that fresh and frozen fish often contain large amounts of the enzymes thiaminases. Freezing appears to increase the concentration of the thiaminases in the tissue of fish, which destroys the vitamin $\mathrm{B}_{1}$ (thiamine); the second problem is an accumulation of fats in the subcutaneous and intramuscular tissue leading to paralysis of the legs, which is caused by particularly oily fish meals (Huchzermeyer, 2002; Huchzermeyer, 2003). For the treatment of nutritional bone disease, it is necessary to rectify the diagnosed deficiency, usually that of calcium. If the affected hatchlings are too weak to feed by themselves, they can initially be dosed or injected intraperitoneal (IP) with calcium borogluconate $(250 \mathrm{mg} / \mathrm{ml})$, at a dosage of $1.5 \mathrm{ml} / \mathrm{kg}$ body mass. The corrected ration should contain additional calcium carbonate, dicalcium phosphate, or sterilized bone meal, to give a final composition containing 1.5-2\% calcium and a Ca:P ratio of 1.5:1 (Huchzermeyer, 2003).

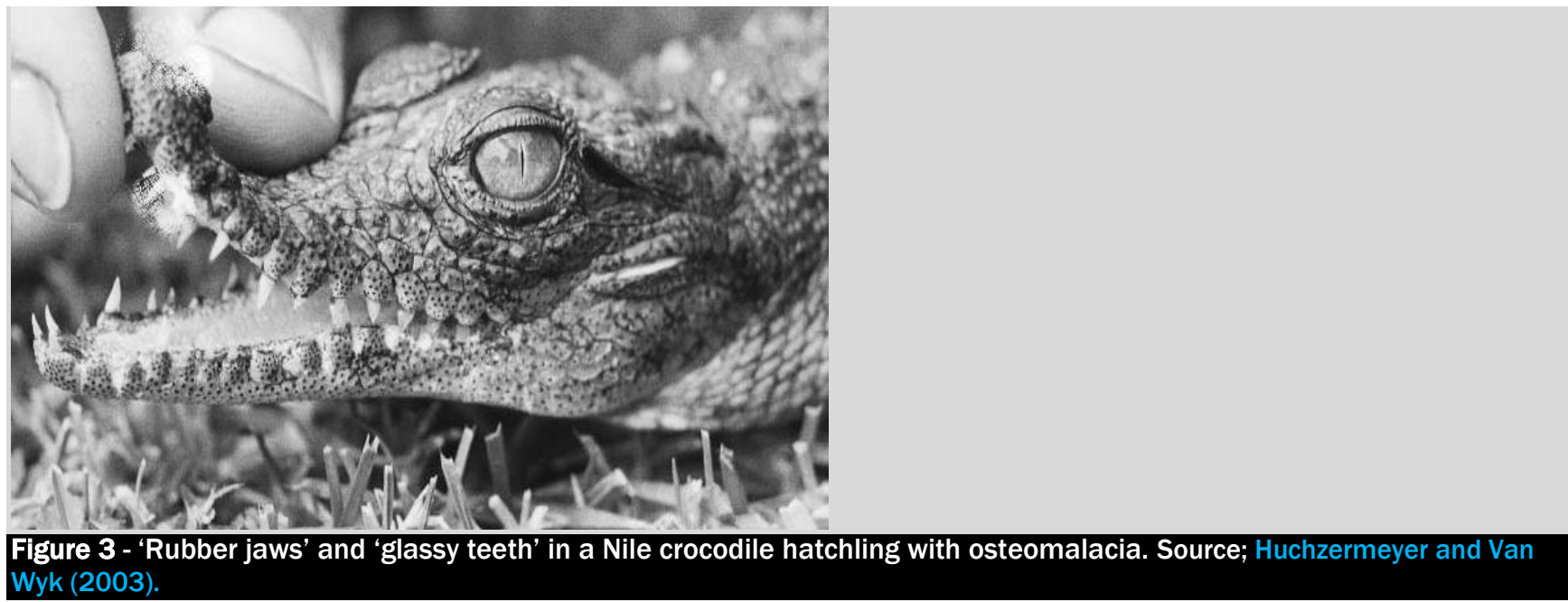

\section{Skin Diseases of Nile crocodiles in AMCR}

Skin lesions were the second most common problems observed at AMCR after paralysis of hind legs (Mahammed, 2008). Dermatophilosis is one of the two-specific bacterial skin infections after Erysipelothrix. The other two known forms, 'winter sores', with yellow-brownish crusty lesions, and chronic stress dermatitis, with patches of white discoloration, particularly on the head around eyes and nostrils, are non-specific and many bacterial species can be involved. No occurrence of dermatophilosis has been reported, yet (Gilber, 2000; Huchzermeyer, 2003). Crocodile pox is one of the viral skin diseases of Nile crocodile, caused by Parapoxvirus. Based on the histopathological diagnosis of the skin lesions, showed the finding of the typical intra-cytoplasmic inclusion bodies. Moreover, fungal infections of the skin occur either locally or generalized under unhygienic conditions in animals with reduced immune capacity due to stress or cold. Superficial infections in the epidermis do not provoke much of an inflammatory response. Deeper infections cause a granulomatous reaction and not an exudative one (fibriscess), as in the case of bacterial infections. The treatment of deep granulomatous lesions may need the application of systemic fungicides, such as ketoconazole. There is no specific treatment; hygienic sanitation is the best prevention provision (Gilber, 2000; Huchzermeyer, 2003).

\section{CONCLUSION AND RECOMMENDATIONS}

Crocodylus niloticus is found in 26 African countries, including Ethiopia. In 1972 commercial hunting of crocodiles was prohibited in Ethiopia and C. niloticus was listed the Nile crocodile in Appendix II of CITES. The decreasing number of species in AMCR affected by low management skills, environmental factors, anthropogenic effects, health problems, and misguided hunting. The isolated causative agents of the species abnormalities require more attention and commitment to resolve the problems. Infectious diseases of bacterial, viral, parasitic, and fungal infections have to be managed wisely and crocodile farmers and other stakeholders in the crocodile industry must focus on causes of the degenerative and 
metabolic disorders. EWCA is losing its foreign currencies income from consumptive and non-consumptive advantages. In conclusion, the office of AMCR must work with professionals and research groups. Besides, the Arba Minch Crocodile Ranch (AMCR) should exercise care and caution when introducing hatchlings from the wild into the Ranch and enhance its husbandry methods to reduce the occurrence of infection and disease. The recommendations by Crocodile Specialist Group (CSG) on Management of Crocodile in Ethiopia should be addressed and implemented.

\section{DECLARATIONS}

\section{Authors' contributions}

All authors contributed equally to this work.

\section{Competing interests}

The authors declare that they have no competing interest.

\section{REFERENCES}

Afonso CL, Tulman ER, Delhon G, Lu Z, Viljoen GJ, Wallace DB, Kutish, GF and Rock DL (2006). Genome of crocodile pox virus. Journal of Virology, 80(10): 4978-4991. Doi: https://doi.org/10.1128/JVI.80.10.4978-4991.2006.

Anon (1992). EPA Code of Practice-Crocodile Farming 2003, Nature Conservation Act 1992.

Antunes NR, Tavio MM, Assuncao P, Rosales RS, Aquili V, De La Fe C, and Poveda JB (2007). In vitro susceptibilities of field isolates of Mycoplasma mycoide. Veterinary Microbiology, 119(1):72-75. Doi: https://doi.org/10.1016/i.vetmic.2006.08.013.

Ariel E (2011). Viruses in reptiles. Veterinary Research, 42(1): 100. Doi: https://doi.org/10.1186/1297-9716-42-100.

Ayling RD, Baker SE, Nicholas RAJ, Peek ML, and Simon AJ (2000). Comparison of in vitro activity of danofloxacin, florfenicol, oxytetracycline, spectinomycin, and tilmicosin against Mycoplasma mycoides subspecies mycoides small colony type. Veterinary Record, 146:243-246. Doi: https://doi.org/10.1136/vr.146.9.243.

Bath O, Kouyate K, and Baker M (1982). New data on Oswaldo fi lariinae (Filaroidea, Nematoda). Bulletin of the National Museum of Natural History, Paris $4^{\text {th }}$ Series, 4: 61-69 Google Scholar

Bayliss HA (1947). IX.-The nematode genus Dujardinascaris in Crocodilia, with a description of a new species. Annales and Magazine of Natural History Series II 6, 123-134. https://doi.org/10.1080/00222934708654617

Bisseru B (1956). On three new species of strigeid trematodes from an African crocodile and the erection of a new family, Neostrigidae. Journal of Helminthology 30, 217-232. DOI: https://doi.org/10.1017/S0022149X00033198

Bisseru B (1957). On two new trematodes (Proterodiplostomatidae) from an African crocodile, and a list of strigeid parasites from Africa. Journal of Helminthology 31: 85-102. DOI: https://doi.org/10.1017/S0022149X00033320

Bolton M. (1997). Managing the Crocodilia: an integrated approach. In Conservation and the Use of Wildlife Resources. Conservation Biology Series, Springer, Dordrecht, 8:111-129. DOI https://doi.org/10.1007/978-94-009-1445-2_7

Botha H, Van Hoven W. and Guillette Jr, L.J. (2011).The decline of the Nile crocodile population in Loskop dam, Olifants River, South Africa. Water SA, 37(1). DOI: https://doi.org/10.4314/wsa.v37i1.64109

Buoro IBJ (1992). Pox-like virus particles in skin lesions of five Nile crocodiles in Kenya. Discovery and Innovation, 4(1):117-118. https://africabib.org/rec.php?RID=Q00007158

Caldwell J (2017). World trade in crocodilian skins 2013-2015. Louisiana, USA: The Louisiana Alligator Advisory Council. https://www.louisianaalligators.com/uploads/1/0/4/8/104800207/iacts17

Caldwell J (2017). World trade in crocodilian skins 2013-2015. Louisiana, USA: The Louisiana Alligator Advisory Council. UNEP-WCMC, Cambridge. https://www.louisianaalligators.com/uploads/1/0/4/8/104800207/iacts17.

Caswell JL and Archambault M (2007). Mycoplasma bovis pneumonia in cattle. Animal Health Research Reviews, 8(2),161-186. Dol: https://doi.org/10.1017/S1466252307001351

Champion G. and Downs CT (2015). Spatial distribution responses of the Nile crocodile (Crocodylus niloticus) to temporal habitat changes in Pongolapoort Dam, KwaZulu-Natal. The Ecology of Nile Crocodile (Crocodylus niloticus) in Pongolapoort Dam, Northern KwaZulu-Natal, South Africa, p.49. http://citeseerx.ist.psu.edu

Cleuren, J and Frits De Vree (2000): Feeding in Crocodilians. In Schwenk, K. ed., 2000. Feeding: form, function, and evolution in tetrapod vertebrates. Elsevier. https://www.academicpress.com

Combrink X Warner JK and Downs CT (2017). Nest-site selection, nesting behavior, and spatial ecology of female Nile crocodiles (Crocodylus niloticus) in South Africa. Behavioral Processes, 135: 101-112. https://doi.org/10.1016/j.beproc.2016.12.006

Cott BH (1961). Scientific results of an inquiry into the ecology and economic status of the Nile crocodile (Crocodylus niloticus) in Uganda and Northern Rhodesia. The transactions of the Zoological Society of London, 29(4): 211-356. Doi: https://doi.org/10.1111/j.10963642.1961.tb00220.x

Davis BM (2001). Improved nutrition and management of farmed crocodiles-hatchling to harvest. Australian Government Rural Industries Research and Development Corporation. RIRDC Project, (01/123).

Dawo F and Mohan K (2007). Development and application of an indirect ELISA test for the detection of antibodies to Mycoplasma crocodyli infection in crocodiles (Crocodylus niloticus). Veterinary Microbiology, 119(2-4): 283-289. https://doi.org/10.1016/j.vetmic.2006.09.003

Dawo $\mathrm{F}$ and Mohan K (2008). Use of immunoblotting to detect antibodies to Mycoplasma crocodyli infection in the sera of crocodiles (Crocodylus niloticus). The Veterinary Journal, 175(2): 279-281. https://doi.org/10.1016/j.tvjl.2007.01.009

Desrosiers R (2001): A review of some aspects of the epidemiology, diagnosis, and control of Mycoplasma hyopneumoniae infections. Journal of Swine Health and production, 9: 233-237. https://www.aasv.org/shap/issues/v9n5/v9n5p233.html

Elsey RM, Joanen T McNease, L. and Lance V (1990a). Stress and plasma corticosterone levels in the American alligator-relationships with stocking density and nesting success. Comparative Biochemistry and Physiology Part A: Physiology, 95(1): 55-63. https://doi.org/10.1016/0300-9629(90)90009-H

Elsey RM, Joanen T, McNease L. and Lance V (1990b). Growth rate and plasma corticosterone levels in juvenile alligators maintained at different stocking densities. Journal of Experimental Zoology, 255(1): 30-36. https://doi.org/10.1002/jez.1402550106

Finger Jr, Thomson JW, Adams PC, Benedict AL, Moran S, and Isberg SR (2015). Reference levels for corticosterone and immune function in farmed saltwater crocodiles (Crocodylus porosus) hatchlings using current Code of Practice guidelines. General and Comparative Endocrinology, 212: 63-72. https://doi.org/10.1016/j.ygcen.2015.01.023 
Foggin CM (1987). Diseases and disease control on crocodile farms in Zimbabwe. Wildlife management: crocodiles and alligators, pp.351362.

Foggin CM (1992. Diseases of farmed crocodiles. Conservation and utilization of the Nile crocodile in South Africa. Handbook on crocodile farming. The Crocodile Study Group of Southern Africa, Pretoria, pp.107-140.

Foggin CM, and Widdowson MA (1996). A Trichinella-like parasite in farmed crocodiles in Zimbabwe. Zimbabwe Veterinary Journal, $27: 86$.

Franklin CE, Davis BM, Peucker SKJ, Stephenson H, Mayer R, Whittier J, Lever J. and Grigg GC (2003). Comparison of stress induced by manual restraint and immobilization in the estuarine crocodile, Crocodylus porosus. Journal of Experimental Zoology Part A: Comparative Experimental Biology, 298(2): 86-92. https://doi.org/10.1002/jez.a.10233

Furstenburg D (2008). Nile Crocodile Crocodylus niloticus (Laurenti, 1768), GEO Wild LTD, Deon Furstenburg. https://www.researchgate.net/profile/Deon_Furstenburg/publication/316167631.

Giglioli GS (1922). The new genus Alofia of the family Linguatulidae. An anatomical account of A. ginae. Journal of Tropical Medicine and Hygiene, 25: 371-377.

Graber M (1981). Internal parasites of domestic and wild vertebrates, other than primates of the People's Republic of Congo (from the Cassard-Chambron collection, 1956-1960). Pathogenic role - prophylaxis. Review of Livestock and Veterinary Medicine of the Tropics, 34: 155-167. PMID: 7335942

Graham A and Gebre A (1997). Numbers and Distribution of Crocodiles and Hippopotamus on Lakes Chamo and Abaya. National Parks Rehabilitation in Southern Ethiopia Project, Technical Report No.13 (Ministry of Agriculture, Addis Ababa), pp. 3.

Grigg G. (2015). Biology and evolution of crocodylians. CSIRO Publishing. Pp. 431-505. Google Book

Grobler M (2013). The use of an inactivated vaccine in farmed Nile Crocodiles (Crocodylus Niloticus) for the control of Mycoplasma Crocodyli infection (Doctoral dissertation, University of Pretoria). http://hdl.handle.net/2263/26217

Hoare CA (1928). Studies on Trypanosoma grayi. 1. The effects of goat's blood. Transactions of the Royal Society of Tropical Medicine and Hygiene, 22(2): 131-136. https://doi.org/10.1016/S0035-9203(28)90004-8

Hoare CA (1929). Studies on Trypanosoma grayi. 2. Experimental Transmission to the Crocodile. Transactions of the Royal Society of Tropical Medicine and Hygiene, 23(1): 39-46. DOI: https://doi.org/10.1016/S0035-9203(29)90831-2

Hoare CA (1931). Studies on Trypanosoma grayi. 3. Life-cycle in the tsetse-fly and in the crocodile. Parasitology, 23(4): 449-484. DOI: https://doi.org/10.1017/S0031182000013858

Horner RF (1988). Poxvirus in farmed Nile crocodiles. The Veterinary Record, 122(19): 459-462. DOI: https://doi.org/10.1136/vr.122.19.459

Huchzermeyer F and Van Wyk W. (2003): Crocodiles - Biology, husbandry, and diseases. Journal of the South African Veterinary Association. 74. https://doi.org/10.4102/jsava.v74i4.529.

Huchzermeyer FW (2002). Diseases of farmed crocodiles and ostriches. Scientific and Technical Review-Office International des Epizooties, 21 (1): 265-276. https://doi.org/10.20506/rst.21.2.1334

Huchzermeyer FW, and Agnagna M. (1994). A survey of parasites and pathology of African dwarf crocodiles Osteolaemus tetraspis in the Congo Republic. In Crocodiles. Proceedings of the $12^{\text {th }}$ Working Meeting of the Crocodile Specialist Group, 2: 309-313).

Huchzermeyer FW, and Cooper JE (2000). Fibriscess, not abscess, resulting from a localized inflammatory response to infection in reptiles and birds. Veterinary Record, 147(18): 515-516. doi: https://doi.org/10.1136/vr.147.18.515

Huchzermeyer FW, Gerdes GH, and Putterill JF (1994). Viruses and mycoplasms from feces of farmed Nile crocodiles. In Proceedings of the $12^{\text {th }}$ working meeting of the Crocodile Specialist Group, IUCN-The World Conservation Union, Gland, Switzerland, May 1994, 2: 303308. G

Huchzermeyer FW, Gerdes GH, Foggin CM, Huchzermeyer KDA, and Limper LC (1994). Hepatitis in farmed hatchling Nile crocodiles (Crocodylus niloticus) due to chlamydial infection. Journal of the South African Veterinary Association 65 (1): $20-22$. https://hdl.handle.net/10520/AJA00382809_1477

Huchzermeyer FW, Huchzermeyer KDA, and Putterill JF (1991). Observations on a field outbreak of poxvirus infection in young Nile crocodiles (Crocodylus niloticus). Journal of the South African Veterinary Association, 62 (1): 27-29. https://www.researchgate.net/profile/John_Putterill/publication/21508621

Huchzermeyer FW, Wallace DB, Putterill JF, and Gerdes GH (2009). Identification and partial sequencing of a crocodile poxvirus associated with deeply penetrating skin lesions in farmed Nile crocodiles, Crocodylus niloticus. Onderstepoort Journal of Veterinary Research, 76(3): 311-316. http://www.scielo.org.za/pdf/ojvr/v76n3/06

Hughes RC, Higginbotham JW, and Clary JW (1941). The trematodes of reptiles, part II, host catalogue. Proceedings of the Oklahoma Academy of Science, 21: 35-43. https://ojs.library.okstate.edu/osu/index.php/OAS/article/viewFile/3147/2863

Hutton JM (1987). Incubation temperatures, sex ratios, and sex determination in a population of Nile crocodiles (Crocodylus niloticus). Journal of Zoology, 211(1): 143-155. https://doi.org/10.1111/j.1469-7998.1987.tb07458.x

Ippen R. and Zwart P (1996). Infectious and parasitic diseases of captive reptiles and amphibians, with special emphasis on husbandry practices which prevent or promote diseases. Scientific and Technical Review-Office International des Epizooties, 15 : 43-54. https://www.researchgate.net/profile/Peernel_Zwart/publication/14281876

Isberg S, Combrink X, Lippai C. and Balaguera-Reina SA (2019). Crocodylus niloticus. The IUCN Red List of Threatened Species 2019: e.T45433088A3010181. http://dx.doi.org/10.2305/IUCN.UK.2019-1.RLTS.T45433088A3010181.en

Isberg S, Shilton C. and Thomson P (2009). Improving Australia's crocodile industry productivity: understanding runtism and survival. Rural Industries Research and Development Corporation, RIRDC Publication No. 09/135, Rural Industries Research and Development Corporation, Australia.

Isberg SR, Thomson PC, Nicholas FW, Barker SG. and Moran C (2005). Quantitative analysis of production traits in saltwater crocodiles (Crocodylus porosus): II. Age at slaughter. Journal of Animal Breeding and Genetics, 122(6): 370-377. https://doi.org/10.1111/i.1439-0388.2005.00549.x

Jacobson ER, Gardiner CH, and Foggin CM (1984). Adenovirus-like infection in two Nile crocodiles. Journal of the American Veterinary Medical Association, 185(11): 1421. PMID: 6096332

Joanen T, McNease L. and Ferguson MWJ (1987). The effects of egg incubation temperature on post-hatching growth of American alligators. Wildlife management: crocodiles and alligators, pp.533-537.

Junker K and Boomker J, (2006). A check-list of the pentastomid parasites of crocodilians and freshwater chelonians. Onderstepoort Journal of Veterinary Research, 73(1): 27-36. https://www.ingentaconnect.com/content/sabinet/opvet/2006

Junker K, Calitz F, Govender D, Krasnov BR. and Boomker JDF (2016). Pentastome assemblages of the Nile crocodile, Crocodylus niloticus Laurenti (Reptilia: Crocodylidae), in the Kruger National Park, South Africa. Folia Parasitologica, 63: 040. https://doi.org/10.14411/fp.2016.040

Kebede W. (2006): Conservation and management of Nile crocodiles in Arba Minch Farm. Arba Minch Crocodile Ranch-AMCR, Ethiopia. unpublished report from Addis Ababa university, College of Veterinary Medicine and Agriculture, Library Data. 
Keymera IF (1974). Report of the pathologist, 1971 and 1972. Journal of Zoology, 173(1): 51-83. https://doi.org/10.1111/j.14697998.1974.tb01747.x

Khosa P, Imbayarwo-Chikosi VE, and Hamandishe V (2012). Comparative analysis of hatching rates and clutch sizes of Nile crocodile (Crocodylus niloticus) eggs collected on-and off-farm in Zimbabwe. Tropical Animal Health and Production, 44(4): 905-909. https://doi.org/10.1007/s11250-011-9985-z

Kirchhoff H, Mohan K, Schmidt R, Runge MR, Brown DR, Brown MB, Foggin CM, Muvavarirwa P, Lehmann H. and Flossdorf J (1997) Mycoplasma crocodyli sp. nov., a new species from crocodiles. International Journal of Systematic and Evolutionary Microbiology, 47(3): 742-746. https://doi.org/10.1099/00207713-47-3-742

Kleven SH (2008). Control of avian Mycoplasma-infections in commercial poultry. Avian diseases, 52(3): 367-374. https://doi.org/10.1637/8323-041808-Review.1

Kofron CP (1990). The reproductive cycle of the Nile crocodile (Crocodylus niloticus). Journal of Zoology, 221(3):477-488. https://doi.org/10.1111/j.1469-7998.1990.tb04014.x

Kofron CP (1991). Courtship and mating of the Nile crocodile (Crocodylus niloticus). Amphibia-Reptilia, 12(1): 39-48. D0I: https://doi.org/10.1163/156853891X00310

Kuttin ES, Müller J, May W, Albrecht F. and Sigalas M (1978). Mycoses in crocodiles. Mykosen, 21(2): 39-48. https://doi.org/10.1111/j.1439-0507.1978.tb01608.x

Lane TJ (1996). Crocodilians. In: Mader, D.R. (ed.) Reptile Medicine and Surgery. W.B. Saunders, Philadelphia, Pennsylvania pp. 336-340.

Leslie AJ and Spotila JR, (2001). Alien plant threatens Nile crocodile (Crocodylus niloticus) breeding in Lake St. Lucia, South Africa. Biological Conservation, 98(3): 347-355. https://doi.org/10.1016/S0006-3207(00)00177-4

Ley DH. and Yoder Jr, HW (2006). Mycoplasma gallisepticum infection, in Diseases of Poultry $11^{\text {th }}$ Ed, edited by Y.M. Saif. Ames: lowa State Press: 12, pp.807-834. https://s3.amazonaws.com/academia.edu.documents/58422112.

Luxmoore RA (1992). Directory of crocodilian farming operations. $2^{\text {nd }}$ edition, IUCN. Gland, Switzerland and Cambridge, UK. 350pp. https://books.google.com.et/books.

Machida M, Araki J, Regoniel PA. and Pontillas FA (1992). Three species of ascaridoid nematodes from crocodile in the Philippines. Bulletin of the National Science Museum. Series A, Zoology, 18(3): 95-102. https://www.cabdirect.org/cabdirect/19940800403

Madsen M (1996). Prevalence and serovar distribution of Salmonella in fresh and frozen meat from captive Nile crocodiles (Crocodylus niloticus). International Journal of Food Microbiology, 29(1): 111-118. https://doi.org/10.1016/0168-1605(95)00020-8

Mahammed M (2008). A Preliminary Study On major health problems and management of Nile crocodile reared on Arba Minch Crocodile farm, DVM Thesis, Addis Ababa University College of Veterinary Medicine and Agriculture, Bishoftu, Debre Zeit Ethiopia. Unpublished report from Addis Ababa university, College of Veterinary Medicine and Agriculture, Library Data.

Manolis SC (1994). Crocodile nutrition. In Crocodiles. Proceedings of the 2nd Regional Meeting of the IUCN-SSC Crocodile Specialist Group. IUCN-CCNT: Darwin, Australia.

Manolis SC, and Webb GJ (2016): Best Management Practices for Crocodilian Farming. IUCN-SSC Crocodile Specialist Group, Australia https://www.iucncsg.org/365 docs.

Marschang RE (2011). Viruses infecting reptiles. Viruses, 3(11): 2087-2126. https://doi.org/10.3390/v3112087

Modesto SP, Anderson JS (2004). The phylogenetic definition of Reptilia. Systematic Biology, 53 (5): 815-821 https://doi.org/10.1080/10635150490503026

Modha, M.L. (1968): Basking behavior of the Nile crocodile on Central Island, Lake Rudolf. African Journal of Ecology, 6(1): 81-88 https://doi.org/10.1111/j.1365-2028.1968.tb00904.x

Mohan K, Foggin CM, Muvavarirwa P, and Honywill J (1995) Mycoplasma-associated polyarthritis in farmed crocodiles (Crocodylus niloticus) in Zimbabwe. Onderstepoort Journal of Veterinary Research, 62: 45-49. http://hdl.handle.net/2263/22265

Mohan K, Sadza, M., Madsen, M., Hill, F.W.G., and Pawandiwa, A. (1994). Phenotypic characterization of Zimbabwean isolates of Pasteurella multocida. Veterinary microbiology, 38(4): 351-357. https://doi.org/10.1016/0378-1135(94)90152-X

Mohan, K., Foggin, C.M., Dziva, F., and Muvavariwa, P. (2001). Vaccination to control an outbreak of Mycoplasma crocodyli infection. Onderstepoort Journal of Veterinary Research, 68: 49-50. http://hdl.handle.net/2263/18401

Mukaratirwa, S. and Foggin, C.M. (1999): Infectivity of Trichinella spp. isolated from Crocodylus niloticus to the indigenous Zimbabwean pig (Mukota). International Journal for Parasitology, 29: 1129-1131. https://doi.org/10.1016/S0020-7519(99)00066-1.

Nisagurwe BE (2017). Economic analysis of Nile crocodile farming in Tanzania: A case study of Kaole crocodile farm, Doctoral dissertation Sokoine University of Agriculture, Bagamoyo. http://www.suaire.suanet.ac.tz:8080/xmlui/handle/123456789/2013

Ocholi RA. and Enurah LU (1989). Salmonellosis in a captive crocodile (Crocodylus niloticus) due to Salmonella choleraesuis. Journal of Zoo and Wildlife Medicine, 20(3): 377-378. http://www.jstor.org/stable/20094977

Ortlepp RJ (1932). Two new ascarids from crocodiles. Journal of the South African Veterinary Medical Association, 3: 70-75. https://www.cabdirect.org/cabdirect/19320800136

Pandey GS, Inoue N, Ohshima K, Okada K, Chihaya Y. and Fujimoto Y (1990). Poxvirus infection in Nile crocodiles (Crocodylus niloticus). Research in Veterinary Science, 49(2): 171-176. https://doi.org/10.1016/S0034-5288(18)31072-5

Perkins LEL, Campagnoli RP, Harmon BG, Gregory CR, Steffens WL, Latimer K, Clubb S. and Crane M (2001). Detection and confirmation of reptilian adenovirus infection by in situ hybridization. Journal of Veterinary Diagnostic Investigation, 13(4): 365-368. https://doi.org/10.1177/104063870101300418

Pfitzer S, Verwoerd DJ, Gerdes GH, Labuschagne AE, Erasmus A, Manvell RJ. and Grund C (2000). Newcastle disease and avian influenza A virus in wild waterfowl in South Africa. Avian diseases, 44: 655-660. https://www.jstor.org/stable/1593107

Piña C. and Larriera A (2002). Caiman latirostris growth: the effect of a management technique on the supplied temperature. Aquaculture, 211(1-4): 387-392. https://doi.org/10.1016/S0044-8486(02)00007-8

Pooley S (2016). A cultural herpetology of Nile crocodiles in Africa. Conservation and Society, 14(4): $391-405$. https://doi.org/10.4103/0972-4923.197609

Pooley T (1982). Discoveries of a crocodile man. HarperCollins. William Collins Sons \& Co., UK. Google Scholar

Radostits OM, Gay CC, Hinchcliff KW. and Constable PD. eds. (2006). Veterinary Medicine E-Book: A textbook of the diseases of cattle, horses, sheep, pigs, and goats. Elsevier Health Sciences, Amsterdam.

Reigh RC. and Williams MB (2013). Amino acid availability of selected plant products and fish meal for American alligator (Alligator mississippiensis). Aquaculture: 412: 81-87. https://doi.org/10.1016/j.aquaculture.2013.07.003

Reinhardt AK, Kemph I, Kobisch M, and Gautier-Bouchardon AV (2002). Fluoroquinolone resistance in Mycoplasma gallisepticum: DNA gyrase as primary target of enrofloxacin and impact of mutations in topoisomerases on resistance level. Journal of Antimicrobial Chemotherapy, 50: 589-592. https://doi.org/10.1093/jac/dkf158

Riley J (1994). A revision of the genus Alofia Giglioli, 1922, and a description of a new monotypic genus, Selfia: two genera of pentastomid parasites (Porocephalida: Sebekidae) inhabiting the bronchioles of the marine crocodile Crocodylus porosus and other crocodilians. Systematic Parasitology, 29: 23-41. https://doi.org/10.1007/BF00009836 
Riley J, and Huchzermeyer FW (1996). A reassessment of the pentastomid genus Leiperia Sambon, 1922 with a description of a new species from both the Indopacific crocodile Crocodylus porosus and Johnston's crocodile C. johnstoni in Australia. Systematic Parasitology, 34: 53-66. https://doi.org/10.1007/BF01531211

Riley J, Hil GF, and Huchzermeyer FW (1997). A description of Agema, a new monotypic pentastomid genus from the lungs of the African dwarf and slender-snouted crocodiles. Systematic Parasitology, 37: 207-217. https://doi.org/10.1023/A:1005803623648

Riley J, Spratt DM, and Winch JM (1990). A revision of the genus Sebekia Sambon, 1922 (Pentastomida) from crocodilians with descriptions of five new species. Systematic Parasitology, 16: 1-25. https://doi.org/10.1007/BF00009598

Rosenbusch RF, Kinyon JM, Apley M, Funk ND, Smith S, and Hoffman LJ (2005). In vitro antimicrobial inhibition profiles of Mycoplasma bovis isolates recovered from various regions of the United States from 2002 to 2003. Journal of Veterinary Diagnostic investigation, 17: 436-441. https://doi.org/10.1177/104063870501700505

Ross JP (1998). Crocodiles: Status survey and conservation action plan (No. 333.957 C938 1998). IUCN, Gland (Suiza). SSC Crocodile Specialist Group. http://www.sidalc.net/cgi-bin/wxis.exe

Sambon LW (1922). A synopsis of the family Linguatulidae. Journal of Tropical Medicine and Hygiene, 25: 188-206. https://www.cabdirect.org/cabdirect/19231000097

Seebacher F, Grigg GC, and Beard LA (1999). Crocodiles as dinosaurs: behavioral thermoregulation in very large ectotherms leads to high and stable body temperatures. Journal of Experimental Biology, 202(1): 77-86. https://jeb.biologists.org/content/jexbio/202/1/77

Shine R (1988). Chapter 4-Parental care in reptiles in Biology of the Reptilia. Volume 16, Ecology B Defense and Life History. C. Gans and RB Huey eds. Alan R. Liss. Inc. New York, USA.

Shirley MH, Carr AN, Nestler JH, Vliet KA, and Brochu CA (2018). Systematic revision of the living African slender-snouted crocodiles (Mecistops Gray, 1844). Zootaxa, 4504(2): 151-193. http://dx.doi.org/10.11646/zootaxa.4504.2.1

Shirley MH, Siege L. and Ademasu M. (2014). Crocodile Management in Ethiopia. Crocodile Specialist Group. https://portals.iucn.org/library/sites/library/files/documents/Rep-2014-007

Siam MA, Salem GH, Ghoneim NH, Michael SA, and El-Refay, MAH (1994). Cryptosporidia in ectotherms and human contacts. Assiut Veterinary Medical Journal, 32: 126-130.

Sprent JFA (1977). Ascaridoid nematodes of amphibians and reptiles: Dujardinascaris. Journal of Helminthology, 51(3): 253-287. https://doi.org/10.1017/S0022149X00007586.

Sprent JFA (1978). Ascaridoid nematodes of amphibians and reptiles: Gedoelstascaris n.g. and Ortleppascaris n.g. Journal of Helminthology, 52: 261-282. https://doi.org/10.1017/S0022149X00005460.

Sprent JFA (1979). Ascaridoid nematodes of amphibians and reptiles: Multicaecum and Brevimulticaecum. Journal of Helminthology, 53 (1): 91-116. https://doi.org/10.1017/S0022149X00005782.

Sprent JFA (1983). Ascaridoid nematodes of amphibians and reptiles: Typhlophorus, Hartwichia, and Trispiculascaris. Journal of Helminthology 57: 179-189. https://doi.org/10.1017/S0022149X00009457.

Staton MA, Edwards Jr HM, Brisbin IL, Joanen T, and McNease L (1990). Protein and energy relationships in the diet of the American alligator (Alligator mississippiensis). The journal of Nutrition, 120(7): 775-785. https://doi.org/10.1093/in/120.7.775

Summers MK. (2015). Aspects of Nile crocodile (Crocodylus niloticus) population ecology and behavior in Pongolapoort Dam, KwaZuluNatal. Doctoral dissertation, University of KwaZulu-Natal. http://hdl.handle.net/10413/13950

Thorbjarnarson J (1999). Crocodile tears and skins: international trade, economic constraints, and limits to the sustainable use of crocodilians. Conservation Biology, 13(3): 465-470. https://www.jstor.org/stable/2641860

Thorbjarnarson JB, Messel H, King FW, and Ross JP (1992). Crocodiles: an action plan for their conservation. IUCN , pp 5. https://books.google.com.et/books

Timothy JP (2018). Reproduction. In Doneley, B., Monks, D., Johnson, R. and Carmel, B. eds. Reptile Medicine and Surgery in Clinical Practice. John Wiley \& Sons. https://doi.org/10.1002/9781118977705

Tosun DD (2013). Crocodile farming and its present state in global aquaculture. Journal of Fisheries Sciences, 7(1): 43. https://doi.org/10.3153/jfscom.2013005

Tracy CR, McWhorter TJ, Gienger CM, Starck JM, Medley P, Manolis SC, Webb GJ. and Christian KA (2015). Alligators and crocodiles have high paracellular absorption of nutrients but differ in digestive morphology and physiology. Integrative and Comparative Biology, 55(6): 986-1004. https://doi.org/10.1093/icb/icv060

Travassos Santos Dias JA (1952). About a species of Hemogregarin parasite of the erythrocytes of Crocodilus niloticus in Mozambique. Annales of the Institute of Tropical Medicine Lisbon, 9: 181-194. PMID: 13008065

Turton JA, Ladds PW, Manolis SC. and Webb GJW (1997). Relationship of blood corticosterone, immunoglobulin and haematological values in young crocodiles (Crocodylus porosus) to water temperature, clutch of origin and body weight. Australian veterinary journal, $75(2)$ : 114-119. https://doi.org/10.1111/j.1751-0813.1997.tb14170.x

Van der Walt ML, Huchzermeyer FW. and Steyn HC (1997). Salmonella isolated from crocodiles and other reptiles during the period 19851994 in South Africa. Onderstepoort Journal of Veterinary Research, 64(4): 277-283. http://hdl.handle.net/2263/20704

Wallace KM. and Leslie AJ (2008). Diet of the Nile crocodile (Crocodylus niloticus) in the Okavango Delta, Botswana. Journal of Herpetology, 42(2): 361-369. https://doi.org/10.1670/07-1071.1

Wellehan JFX, Johnson AJ, Harrach B, Benkö M, Pessier AP, Johnson M, Garner M, Childress A, and Jacobson ER (2004). Detection and analysis of six lizard adenoviruses by consensus primer PCR provides further evidence of a reptilian origin for the adenoviruses. Journal of Virology, 78: 13366-13369. https://doi.org/10.1128/JVI.78.23.13366-13369

Whitaker R (2007). African Parks (Ethiopia) Nechsar National Park Project. Sustainable Use of the Lake Chamo Nile Crocodile Population. Project Document. African Parks (Ethiopia), Addis Ababa. https://www.iucncsg.org/365 docs/attachments/protarea/Lake-4095a439

Yeshdenber T (1994). Crocodiles Production and its present status in Ethiopia, A Seminar Paper, College of Veterinary Medicine and Agriculture, Addis Ababa University. Library Data. 